\title{
Analisis CFD Hambatan Lambung Kapal Trimaran Asimetris Flat Side Inside dengan Variasi Jarak Antar Lambung Secara Membujur
}

\author{
Andrew Gibson, dan I Ketut Aria Pria Utama \\ Jurusan Teknik Perkapalan, Fakultas Teknologi Kelautan, Institut Teknologi Sepuluh Nopember (ITS) \\ Jl. Arief Rahman Hakim, Surabaya 60111 Indonesia \\ e-mail:kutama@na.its.ac.id
}

\begin{abstract}
Abstrak-Kapal dibuat dengan fungsi sebagai sarana transportasi untuk kebutuhan niaga maupun perang. Saat ini kebutuhan kapal cepat meningkat sehingga diperlukan kapal dengan bentuk multihull, salah satunya adalah kapal Trimaran. Kapal Trimaran merupakan kapal yang mempunyai 3 lambung, yaitu satu mainhull dan dua side-hull atau disebut juga outriggers sehingga mempunyai nilai stabilitas yang tinggi. Untuk itu, perlu dilakukan penelitian lebih lanjut untuk membuat kapal Trimaran yang memiliki hambatan yang kecil sehingga dapat menambah nilai ekonomis dari segi efisiensi mesin dan performa kapal yang baik. Berbagai bentuk badan kapal kemudian dikembangkan untuk mendapatkan desain lambung kapal Trimaran yang paling optimum salah satunya adalah kapal Trimaran flat side inside, yaitu sebuah konfigurasi baru dengan lambung yang memiliki bidang datar atau asimetris di dalam. Penelitian ini bertujuan untuk mendapatkan variasi letak stagger atau jarak antar lambung secara membujur (R/L) kapal Trimaran asimetris flat side inside yang menghasilkan hambatan paling kecil dengan menggunakan bantuan software Computational Fluid Dynamics (CFD). Dengan melakukan variasi kecepatan yaitu 12, 14, 16, dan 22 knots dan variasi jarak antar lambung $(R / L)$ dimana $R$ merupakan jarak antar lambung secara membujur dan $L$ adalah panjang kapal mainhull, yaitu untuk $R / L=0.1, R / L=$ 0.2 dan $R / L=0.3$ pada ketentuan jarak antar lambung secara melintang $(\mathrm{S} / \mathrm{L})=0.4$ dapat dilihat pengaruh interaksi gelombang terhadap nilai hambatan gelombang kapal Trimaran asimetris flat side inside. Hasil pengujian didapatkan bahwa model $C$ dengan $R / L=0,3$ dan $S / L=0,4$ adalah variasi model paling baik dalam penelitian ini karena menghasilkan hambatan kekentalan dan hambatan total terkecil dengan presentase yang dibandingkan dengan model awal masingmasing $7,1 \%$ dan $25,0 \%$.
\end{abstract}

Kata Kunci-Trimaran, Flat Side Inside, Hambatan, Letak Stagger, Computational Fluid Dynamics (CFD)

\section{PENDAHULUAN}

$\mathrm{B}$ ERDASARKAN informasi dari militer pertahanan dan keamanan, negara Indonesia sendiri membutuhkan banyak kapal cepat rudal (KCR) untuk mengimbangi wilayah laut yang begitu luas dan daratan yang tersebar. Keberadaan kapal cepat seperti KCR dinilai mampu mempermudah TNI maupun para pengelola keamanan di laut untuk mengamankan wilayah maritim Indonesia.

Sehubungan dengan bertambahnya produksi kapal cepat, dunia perkapalan saat ini sedang gencar untuk melakukan studi mengenai rancangan model kapal multihull. Keuntungan kapal multihull yaitu memiliki stabilitas melintang yang lebih baik daripada kapal monohull [1].

Dengan merubah single body menjadi multihull serta dengan melakukan pengaturan jarak antar hull maka akan diperoleh perilaku hidrodinamis yang lebih baik [2]. Kapal Trimaran adalah kapal multi-hull, yang terdiri dari satu lambung utama (mainhull) dan dua lambung cadik (sidehulls) atau disebut juga outriggers yang ukurannya lebih pendek dan terletak di kedua sisi lambung utama.

\section{TINJAUAN PUSTAKA}

\section{II.1 Trimaran}

Kapal Trimaran merupakan kapal yang mempunyai tiga lambung, yaitu satu mainhull dan dua side-hull atau disebut juga outriggers sehingga mempunyai nilai stabilitas yang tinggi [3]. Bentuk lambung trimaran adalah pengembangan dari bentuk lambung tunggal yang bertujuan untuk meningkatkan kecepatan kapal yang diikuti dengan berkurangnya daya yang dibutuhkan. Bentuk lambung kapal Trimaran didesain untuk mendapatkan stabilitas melintang yang lebih baik dibandingkan kapal monohull.

Untuk kapal Trimaran terdapat perbedaan dalam perhitungan hambatannya dikarenakan mempunyai bentuk lambung kapal yang berbeda. Hambatan dan gelombang yang dihasilkan oleh kapal Trimaran dipengaruhi oleh berbagai hal, yaitu [4]:

1. Jarak side-hull dengan center hull secara melintang (clearance) dan longitudinal (stagger).

2. Perbandingan displacement dari mainhull dan sidehull.

3. Pebedaan tinggi dari sidehull dan center hull.

4. Kecepatan dari kapal Trimaran.

5. Perbandingan-perbandingan dalam ratio dari parameter kapal Trimaran.

\section{II.2 Konfigurasi Lambung Trimaran}

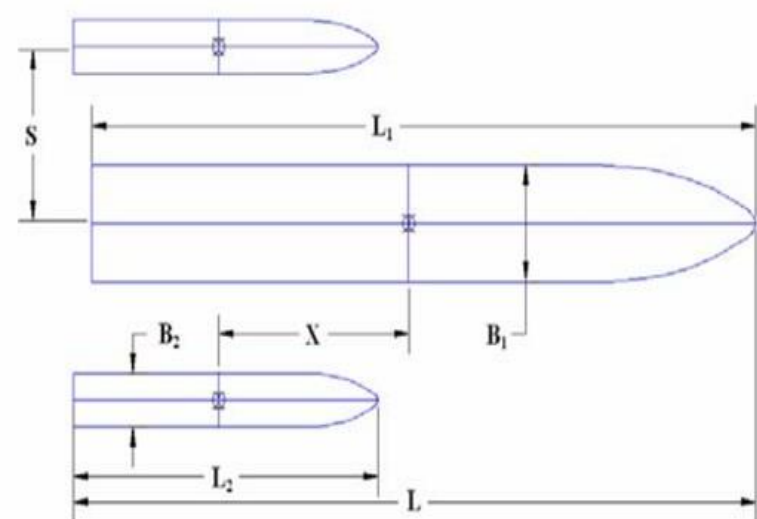

Gambar 1. Konfigurasi Bentuk Membujur untuk Kapal

Berikut ini adalah bentuk - bentuk dari lambung Trimaran. Ada 3 bentuk atau model dari lambung Trimaran [5]:

(i). Simestris

(ii). Asimetris in-board / Flat side outside

(iii). Asimetris out-board / Flat side inside 


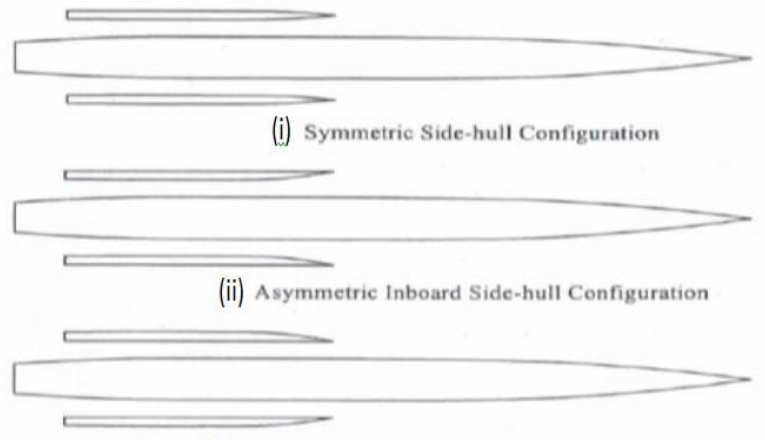

(iii) Asymmetric Outboard Side-hull Configuration

Gambar 2. Bentuk outriggers pada Trimaran

\section{II.3 Hambatan Kapal}

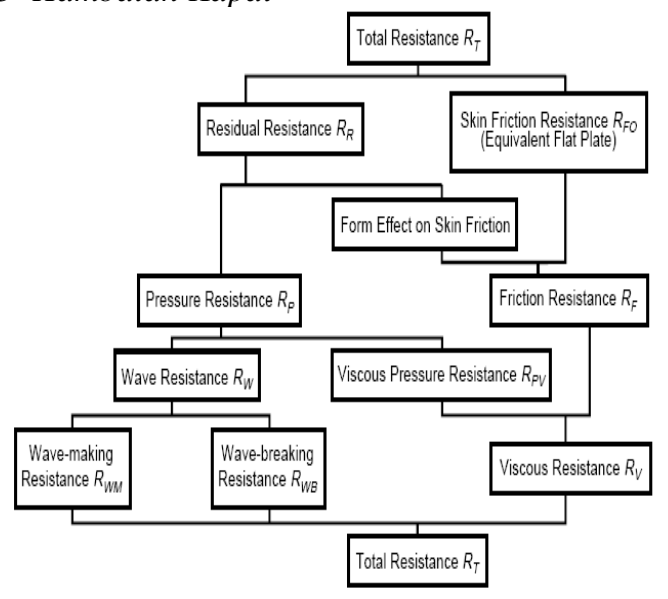

Gambar 3. Diagram Komponen Koefisien Hambatan Total Kapal [6]

Komponen hambatan total secara singkat dapat dijelaskan sebagai berikut:

a) Tahanan Gesek, $\mathrm{R}_{\mathrm{F}}$ : merupakan komponen tahanan yang direroleh dengan mengintegralkan tegangan tangensial ke seluruh permukaan basah kapal menurut arah gerakan kapal.

b) Tahanan sisa, $\mathrm{R}_{\mathrm{R}}$ : merupakan kuantitas hasil pengurangan tahanan total badan kapal, dengan suatu tahanan gesek yang merupakan hasil prhitungan yang diperoleh dengan memakai rumus khusus.

c) Tahanan kekentalan, $\mathrm{R}_{\mathrm{V}}$ : merupakan tahanan yang terkait dengan energy yang dikeluarkan akibat pengaruh viscous.

d) Tahanan Tekanan, $\mathrm{R}_{\mathrm{P}}$ : merupakan tekanan yang diperoleh dengan mengintegralkan tegangan normal ke seluruh permukaan benda menurut arah gerak benda.

e) Tahanan Tekanan Kekentalan, $\mathrm{R}_{\mathrm{PV}}$ : merupakan komponen tahanan yang diperoleh dengan mengintegralkan komponen tegangan normal akibat kekentalan dan turbulensi.

f) Tahanan gelombang (Wave making resistance), $\mathrm{R}_{\mathrm{W}}$ : merupakan komponen tahanan yang terkait dengan energy yang dikeluarkan untuk menimbulkan gelombang gravitasi.

g) Tahanan pola Gelombang (Wave Pattern Resistance), $\mathrm{R}_{\mathrm{WP}}$ : komponen tahanan yang disimpulkan dari hasil pengukuran elevasi gelombang yang jauh dari kapal dan model. Tahanan ini disimpulkan demikian tidak termasuk tahanan pemecah gelombang (wavebreaking resistance). h) Tahanan pemecah gelombang, $\mathrm{R}_{\mathrm{WB}}$ : merupakan komponentahanan yang terkait dengan pemecahan gelombang yang berada diburitan kapal.

i) Tahanan Semprotan (Spray Resistance) $\mathrm{R}_{\mathrm{S}}$ : merupakan komponen tahanan yang terkait dengan energy yang dikeluarkan untuk menimbulkan semprotan.

j) Sebagai tambahan atas komponen tahanan tersebut, beberapa tahanan tambahan, RA, perlu pula disebutkan:

k) Tahanan Anggota Badan (Appendage Resistance): merupakan tahanan dari bos poros, penyangga poros (shaft brackets), poros, lunas bilga, daun kemudi dan sebagainya.

1) Tahanan Kekasaran: merupakan tahanan akibat kekasaran, kekasaran akibat korosi dan fouling (pengotoran)pada badan kapal.

m) Tahanan kemudi (Steering resistance): untuk mempertahankan kelurusan lintasan, koreksi kedudukan biasanya dilakukan dengan memakai daun kemudi. Pemakaian daun kemudi menyebabkan timbulnya komponen tahanan yang disebut tahanan kemudi.

\section{II.4 Governing Equations}

Computational Fluids Dynamic (CFD) merupakan metode numerik dalam perhitungan, prediksi dan pendekatan aliran fluida dengan bantuan perangkat lunak (software) pada computer. CFD menggunakan persamaan dinamika fluida, yaitu persamaan kontinuitas, momentum, dan energi. Berikut ini adalah persamaan kontinuitas:

$$
\frac{\partial u}{\partial x}+\frac{\partial v}{\partial y}+\frac{\partial w}{\partial z}=0
$$

Persamaan (1) menyatakan bahwa laju peningkatan (pengurangan) massa di dalam suatu elemen sama dengan laju netto aliran massa ke dalam (keluar) elemen fluida tersebut. Pada aliran incompressible, rapat massa konstan, laju perubahan massa di dalam elemen adalah nol. Ketiga suku bagian kiri pada Persamaan (1) adalah aliran massa netto yang keluar elemen melalui dinding elemen dan disebut dengan suku konvektif. Persamaan dasar yang digunakan dalam CFD adalah persamaan Navier-Stokes. Dalam persamaan ini, asumsi pertama adalah bahwa fluida incompressible (tidak dapat dimampatkan), yang mengarah ke persamaan lain: kekekalan massa (conservation of mass). Bentuk umum persamaan Navier-Stokes:

$$
\rho\left(\frac{\partial V}{\partial t}+v \cdot \nabla v\right)=-\nabla p+\mu \nabla^{2} v+f
$$

Dimana kecepatan aliran (V), perpindahan $\nabla, \quad$ massa jenis fluida $(\rho)$, frictional resistance $(\mu)$, gaya luar seperti gaya gravitasi (f) dan waktu (t).

Pada CFD digunakan pemodelan turbulent $K$-Epsilon $(K-\mathcal{E})$ untuk pemodelan kekentalan murni dan Shear Stress Transport $(K-\omega)$ untuk pemodelan full viscous. Metode penyelesaian governing equation adalah metode diskrit. Beberapa metode diskrit yang digunakan adalah Finite Element Method (FEM) untuk analisis struktural dan Finite Volume Method (FVM) untuk CFD. FVM menggunakan persamaan:

$$
\frac{\partial}{\partial t} \iiint Q d V+\iint F d \mathbf{A}=0
$$


Dimana Q adalah vektor variabel, F adalah vektor fluks, V adalah volume dari elemen kontrol volume, dan luas permukaan elemen volume kontrol.

\section{METODE PENELITIAN}

\section{III.1 Pemodelan Kapal Trimaran}

Untuk perancangan model kapal Trimaran menggunakan program Maxsurf, dimana perancangan tersebut mengacu pada dimensi kapal yang terdapat dalam jurnal dari penelitian sebelumnya oleh [7] yang meneliti kapal Trimaran dengan tipe lambung yang sama dengan penelitian ini yaitu flat side inside. Berikut data ukuran utama untuk mainhull dan sidehull yang digunakan dalam pemodelan:

\begin{tabular}{|c|r|r|}
\hline Ukuran Utama & MainHull & SideHull \\
\hline LOA (m) & 60.83 & 22 \\
Lwl (m) & 56.61 & 22 \\
B (m) & 4.24 & 1.05 \\
T (m) & 2.5 & 1.61 \\
H (m) & 7.5 & 6.61 \\
LCB (dari belakang) & 26.825 & - \\
Displ (ton) & 256.164 & 16.953 \\
V (m3) & 249.916 & 16.539 \\
\hline Main hull relation & & \\
Main hull L/B & 13.35 & \\
Main hull B/T & 1.7 & \\
Main hull H/T & 3 & \\
\hline Main-Side hull relation & & \\
Side/Main hull L/L & & 0.39 \\
Side/Main hull T/T & & 0.64 \\
Side/Main hull B/B & & 0.25 \\
\hline
\end{tabular}

Gambar 4. Data Kapal Pembanding

Berikut hasil pemodelan dan juga setelah divariasikan jarak antar lambungnya secara membujur:

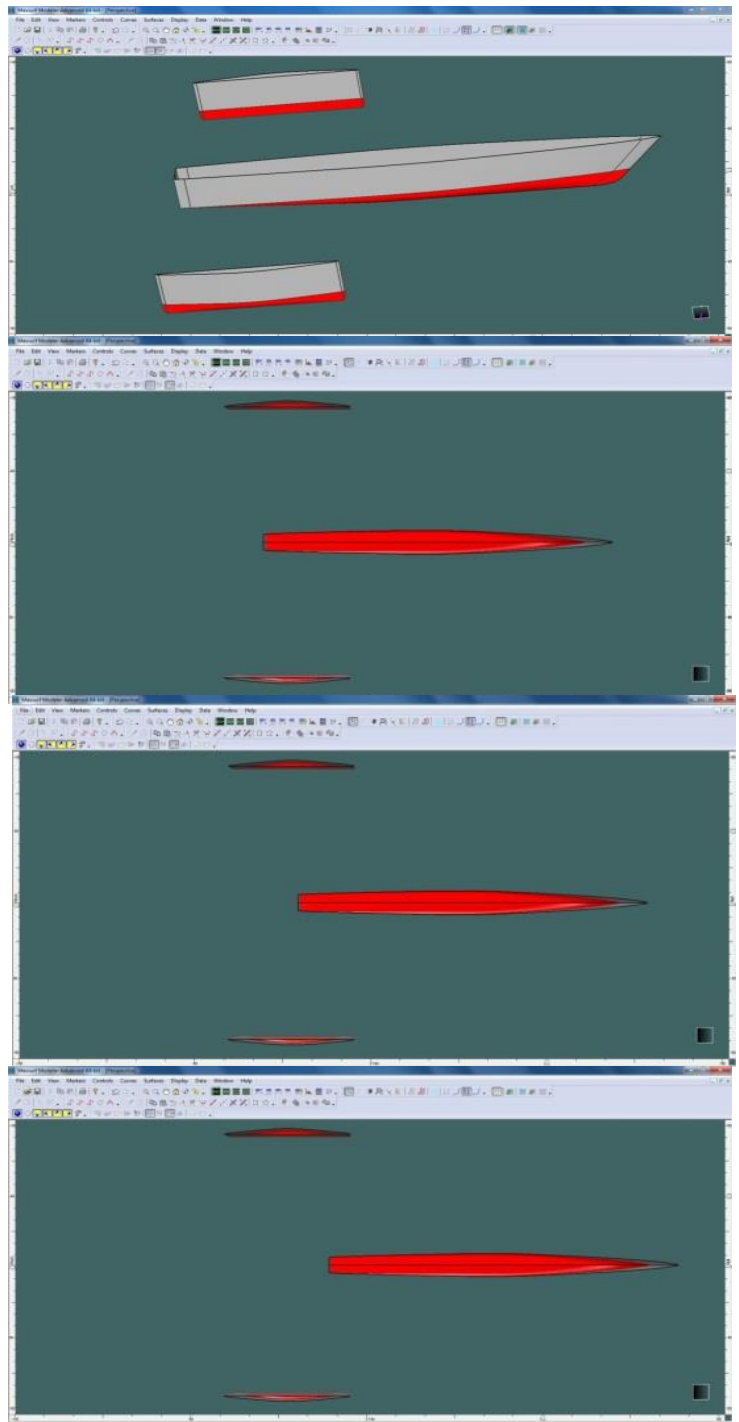

Gambar 5. Model Awal, Model A, Model B, dan Model C III.2 Pemodelan Kekentalan Murni dan Free Surface dalam CFD

Pada penelitian ini menggunakan dua kondisi pemodelan untuk mendapatkan hambatan total dan hambatan kekentalan. Model pertama merupakan pemodelan dengan mendefinisikan bahwa seluruh badan kapal dibawah permukaan air atau sarat terbenam. Pemodelan ini dilakukan untuk mendapatkan hambatan kekentalan dari model kapal. Model kedua merupakan pemodelan dengan menerapkan free surface yaitu pemodelan kapal dengan menggunakan dua fluida. Pemodelan dengan menggunakan dua fluida menggunakan fluida air dan udara dalam proses simulasi. Pemodelan dengan menerapkan kondisi ini memungkinkan diperoleh hambatan total kapal tanpa mengabaikan adanya beberapa air yang naik dari batas sarat kapal.

Perhitungan hambatan total dan hambatan kekentalan dilakukan pada tiap-tiap model kapal Trimaran dengan variasi kecepatan yang sudah ditentukan. Hasil pemodelan ditampilkan pada Gambar 6 sebagai berikut:

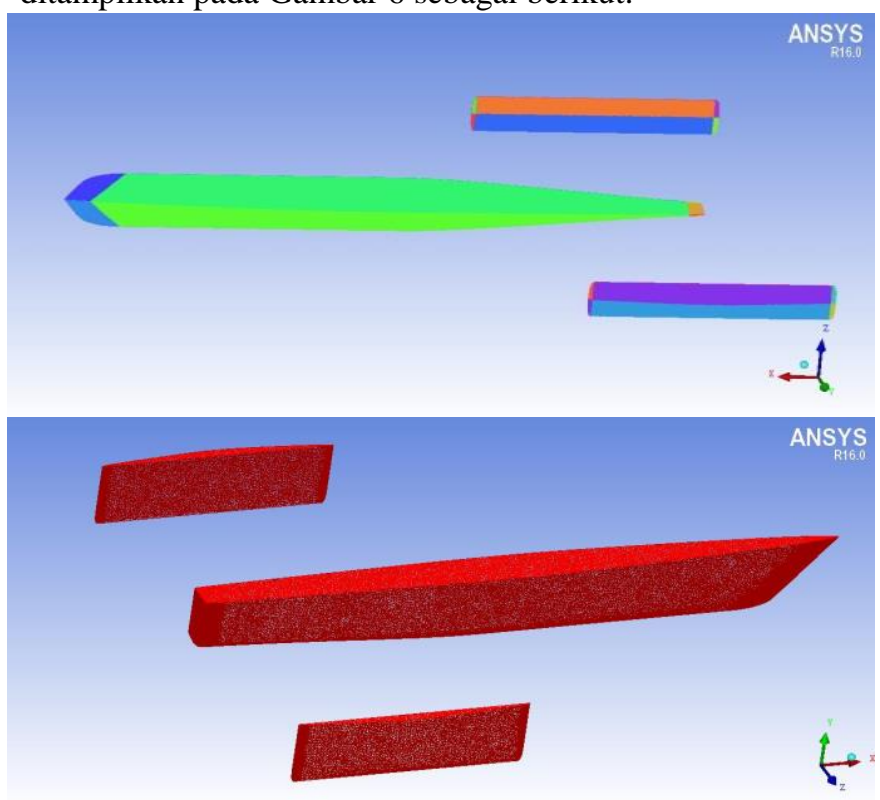

Gambar 6. Model Kekentalan Murni (atas) dan Free Surface (bawah)

\section{ANALISIS DAN PEMBAHASAN}

\section{IV.1 Perbandingan Hambatan Kekentalan}

Tabel 1. Nilai Hambatan Kekentalan untuk setiap Variasi Model

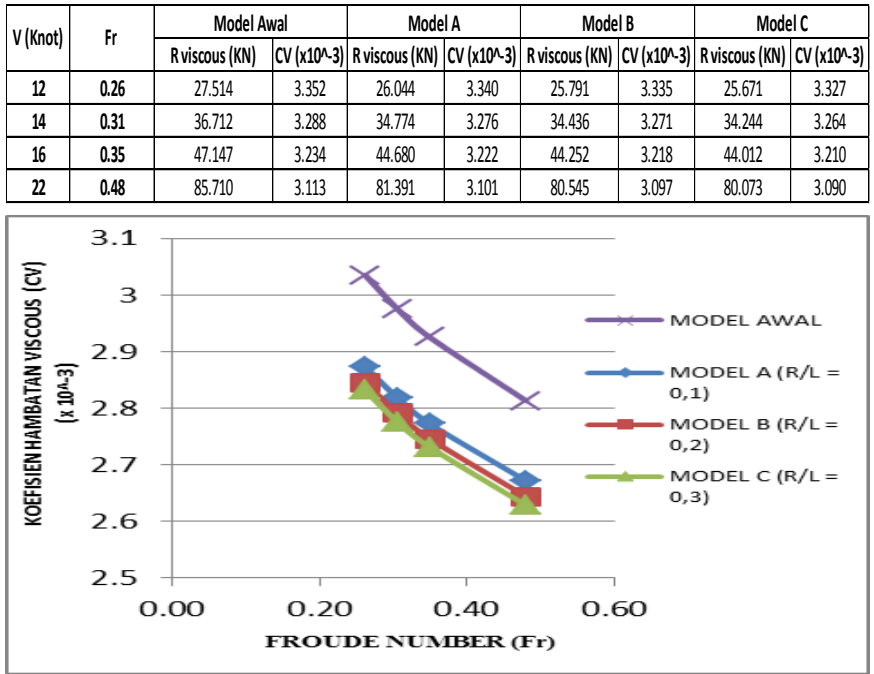


Diketahui bahwa besarnya hambatan kekentalan berbanding lurus dengan bertambahnya nilai angka Froude. Kenaikan nilai hambatan kekentalan seiring meningkatnya angka Froude menunjukkan besarnya pengaruh dari komponen hambatan gesek dalam menghasilkan hambatan kekentalan. Perbedaan tekanan dan kecepatan aliran dapat mempengaruhi besarnya hambatan kekentalan. Dalam hal ini Model $\mathrm{C}$ menghasilkan hambatan kekentalan yang lebih kecil dari variasi model lainnya (7,1\% dibandingkan dengan model awal).

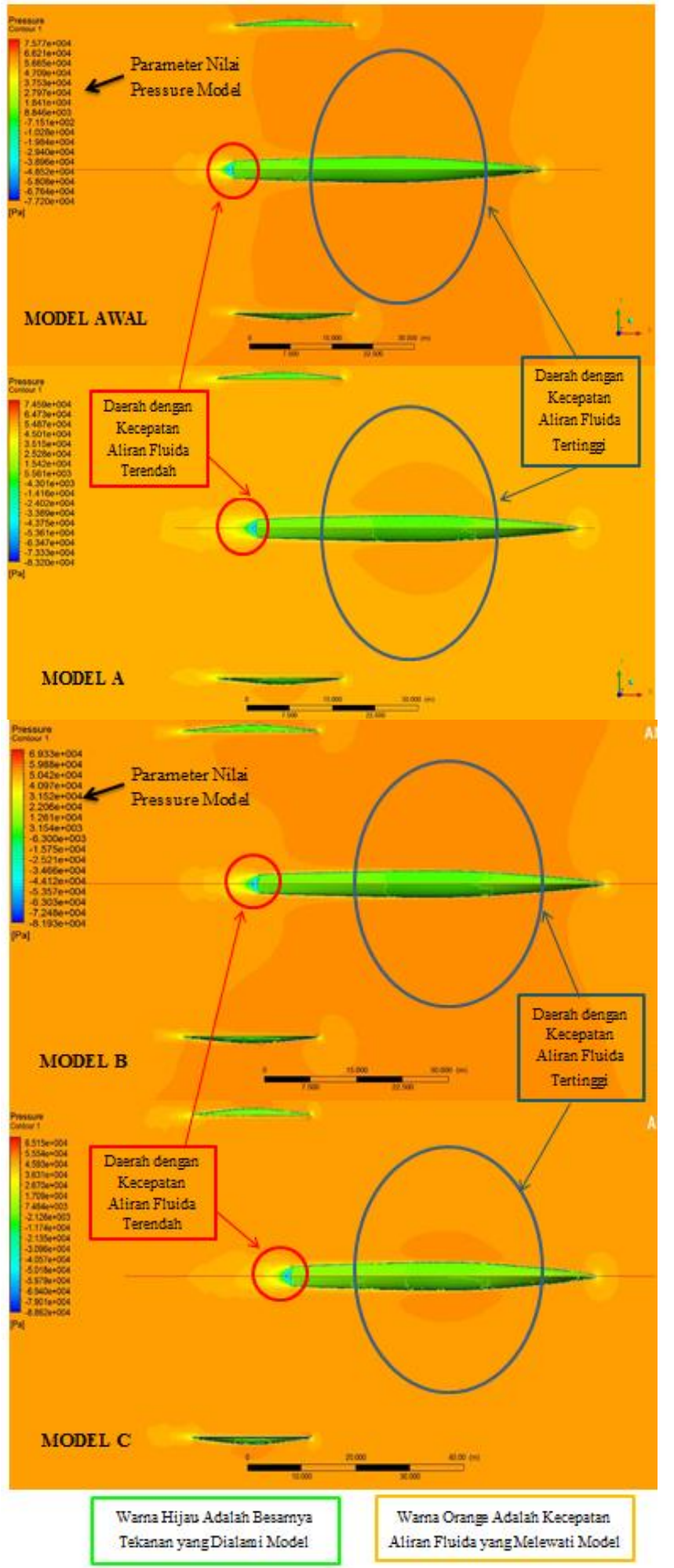

Gambar 8. Kontur Tekanan (warna hijau pada model) dan

Kecepatan Aliran Fluida (warna orange) pada Model Kekentalan Murni

Hambatan kekentalan juga dipengaruhi oleh hambatan tekanan (Pressure drag) yang merupakan gaya normal akibat tekanan fluida di sekitar lambung. Tekanan fluida ini dipengaruhi oleh kecepatan aliran di sekitar lambung kapal Trimaran baik mainhull maupun sidehull.

Karena perbedaan tekanan dan kecepatan aliran yang tidak sama terhadap garis tengah (centerline) lambung maka pada bagian sekitar lambung Trimaran terjadi peningkatan usikan kecepatan aliran yang ditunjukkan dengan warna orange (yang dilingkari warna biru untuk kecepatan aliran fluida tertinggi) pada Gambar 8. Peningkatan usikan kecepatan aliran ini menyebabkan perubahan struktur lapisan batas (boundary layer) dan juga luas bidang basah (WSA) pada permukaan lambung.

Dari hasil parameter nilai pressure model dalam CFD (lihat Gambar 8), maka dapat disimpulkan bahwa model C menghasilkan nilai pressure terendah untuk semua variasi model dengan variasi jarak antar lambung secara melintang (S/L) yang sama yaitu 0.4. Hal ini disebabkan karena jarak antar lambung secara membujur (R/L) pada Model C lebih jauh daripada variasi model lainnya, sehingga gangguan atau interferensi terhadap kecepatan aliran fluida semakin kecil.

Ini memenuhi prinsip Bernoulli dalam dinamika fluida dimana prinsip dasar Bernoulli bahwa untuk aliran inviscid, peningkatan kecepatan fluida terjadi bersamaan dengan penurunan tekanan atau penurunan energi potensial fluida. Nilai pressure menghasilkan hambatan tekanan (Pressure drag) yang semakin menurun seiring bertambahnya jarak antar lambung secara membujur (R/L). Hambatan kekentalan kapal akan semakin bertambah apabila terjadi penurunan nilai jarak antar lambung secara membujur R/L [8].

\section{IV.2 Perbandingan Hambatan Total}

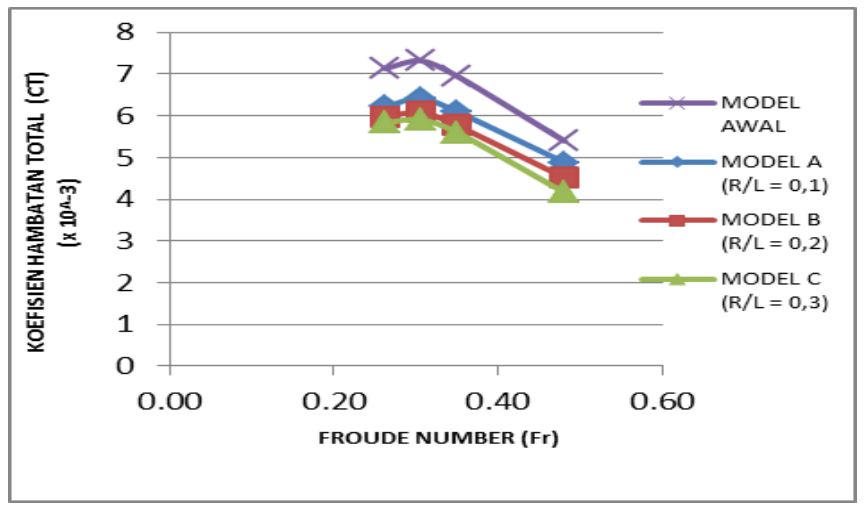

Gambar 9. Grafik Hambatan Total

Model C menghasilkan hambatan total yang paling kecil dengan presentase pengurangan hambatan total sebagai berikut: model Awal dengan model A sebesar 13,3\%, model Awal dengan model B adalah sebesar $19.9 \%$, dan model Awal dengan model C adalah $25.0 \%$ untuk kisaran angka Froude 0,26 - 0,48. Hambatan total paling kecil dihasilkan oleh model dengan sidehulls terjauh [9].

\section{IV.3 Perbandingan Hambatan Gelombang}

Tabel 3. Nilai Hambatan Gelombang untuk setiap Variasi Model

\begin{tabular}{|c|c|c|c|c|c|c|c|c|c|}
\hline \multirow{2}{*}{ V(Knot) } & \multirow{2}{*}{ F" } & \multicolumn{2}{|c|}{ ModelAwal } & \multicolumn{2}{|c|}{ ModelA } & \multicolumn{2}{|c|}{ Model B } & \multicolumn{2}{|c|}{ ModelC } \\
\hline & & RGELOMBANG /KN & CW/ $/ 1013$ & RGELOMBANG |KN) & CW/ $\times 10$. & RGELOMBANG |KN & CW $(x 10.3)$ & RGELOMBANG |KN & v) $C W(x 10.3)$ \\
\hline 12 & 0.26 & 37,133 & 4.006 & 30.264 & 3,338 & 28.323 & 3.124 & 27.249 & 3.06 \\
\hline 14 & 0.31 & 53.646 & 4,347 & 4.560 & 3.611 & 40.690 & 3.297 & 38.696 & 3.136 \\
\hline 16 & 0.35 & 64.996 & 4.033 & 53.674 & 3,330 & 48.780 & 3.027 & 46.342 & 2.875 \\
\hline
\end{tabular}




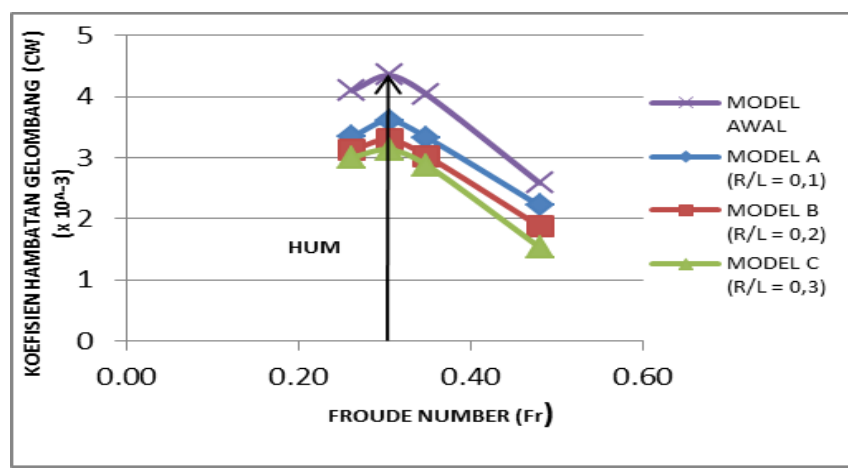

Gambar 10. Grafik Hambatan Gelombang

Ketika posisi sidehulls dipindahkan ke belakang (stagger negative) maka hump akan mulai terbentuk pada angka Froude sekitar 0,3 [8]. Hump terjadi ketika 2 puncak gelombang bertemu pada waktu yang sama, sehingga timbul hasil superposisi gelombang yang sangat tinggi dan dipengaruhi oleh panjang dan kecepatan Kapal [10].

\section{IV.4 Hubungan Komponen Hambatan}

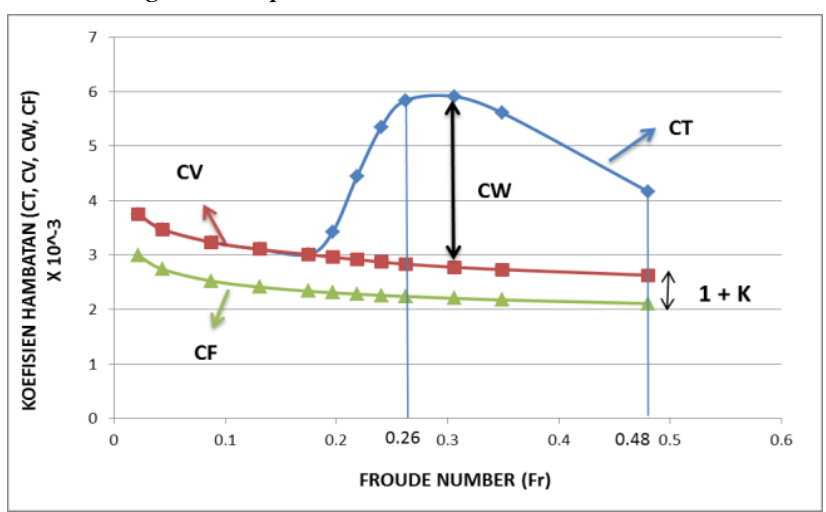

Gambar 11. Grafik Komponen Hambatan

Pada angka Froude 0,26 sampai 0,35 pengaruh lebih besar disebabkan dari hambatan gelombang, kemudian pada variasi angka Froude terbesar dalam penelitian ini yaitu 0,48 , efek interferensi gelombang mulai berkurang sehingga hambatan total lebih dihasilkan dari hambatan kekentalan [9].

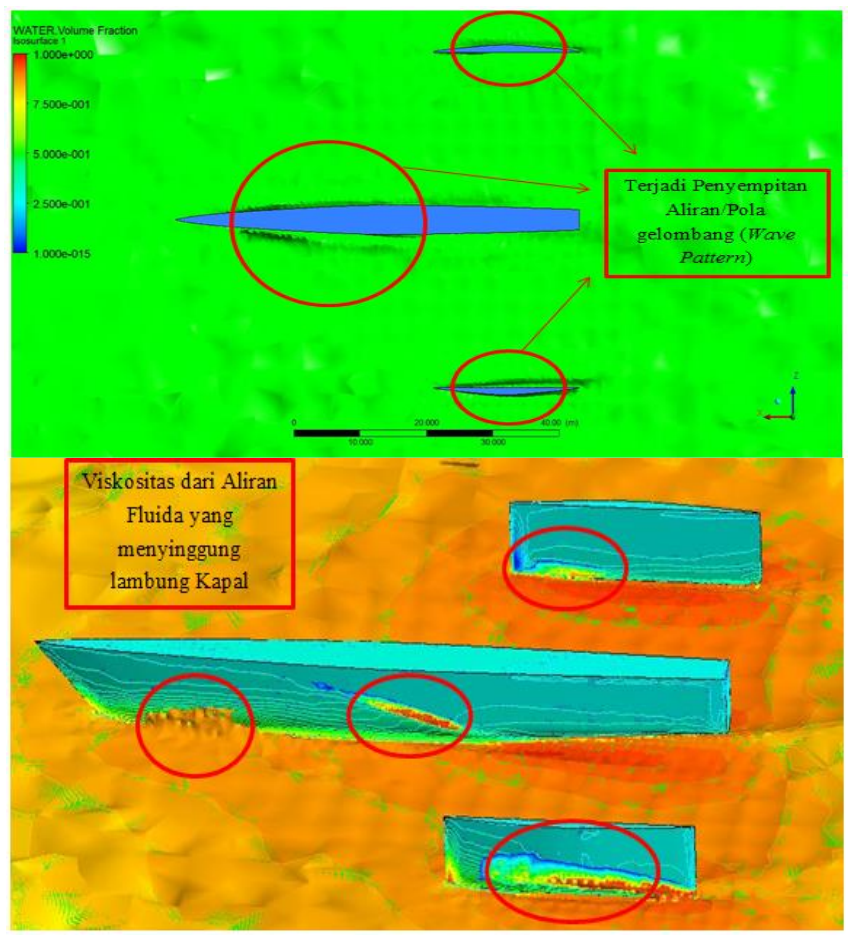

Gambar 12. Hasil Simulasi Gelombang

Aliran atau pola gelombang yang menyempit membuat efek interferensi antara gelombang yang disebabkan oleh mainhull dan sidehulls semakin kecil, sedangkan kekentalan fluida yang menyinggung lambung kapal secara tangensial semakin besar. Akibatnya, hambatan kekentalan cenderung lebih mempengaruhi hambatan total dibandingkan dengan hambatan gelombang pada Fr 0,48.

\section{IV.5 Efek Interferensi $S / L=0,4$ pada Trimaran Flat Side Inside}

Tabel 4. Selisih Trimaran Model Awal dengan Trimaran Lambung Terpisah

\begin{tabular}{|c|c|c|c|c|c|c|}
\hline \multirow{2}{*}{$V($ Knot $)$} & \multirow{2}{*}{$\mathrm{Fr}$} & \multicolumn{2}{|c|}{ Trimaran Model Awal } & \multicolumn{2}{|c|}{ Trimaran Lambung Terpisah } & \multirow{2}{*}{ Selsisih\% } \\
\hline & & Hambatan Total (KN) & $C T\left(x 10^{n-3}\right)$ & Hambatan Tota (KN) & $C T\left(x 10^{n}-3\right)$ & \\
\hline 12 & 0.26 & 64.647 & 7.13 & 57.1 & 6.298 & 13.217 \\
\hline 14 & 0.31 & 90.358 & 7.32 & 87.9 & 7.123 & 2.796 \\
\hline 16 & 0.35 & 112,143 & 6.96 & 112.9 & 7.005 & 0.671 \\
\hline 22 & 0.48 & 164.445 & 5.40 & 165.2 & 5.421 & 0.457 \\
\hline
\end{tabular}

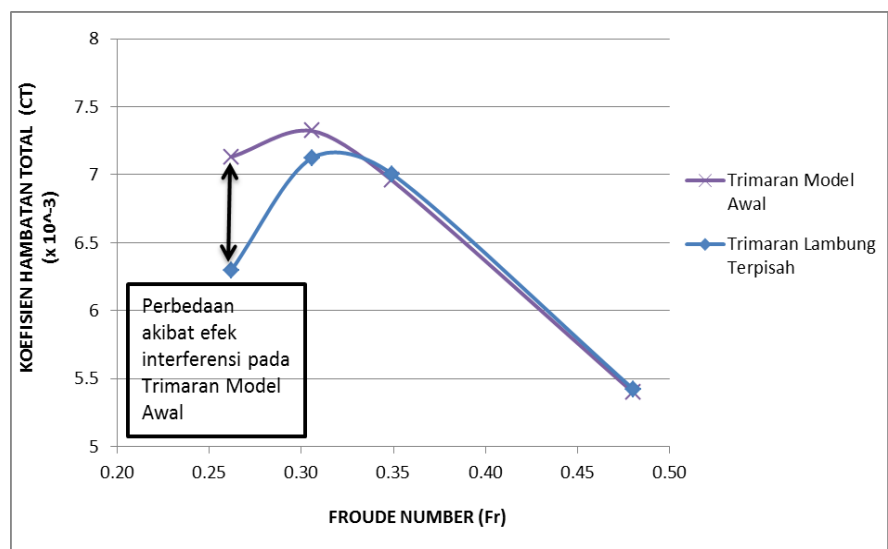

Gambar 13. Grafik Selisih Trimaran Model Awal dengan Trimaran Lambung Terpisah

Masih terdapat efek interferensi pada kapal Trimaran flat side inside dengan $\mathrm{S} / \mathrm{L}=0,4$ karena terdapat perbedaan hasil nilai hambatan total antara trimaran model awal (lambung secara utuh diuji) dengan trimaran lambung terpisah (tiaptiap lambung diuji secara terpisah kemudian dijumlahkan). Perbedaan terbesar dialami pada angka Froude 0,26 (dengan selisih $13,2 \%$ ) dan seterusnya mulai berkurang sampai pada perbedaan terkecil pada angka Froude 0,48 (dengan selisih $0,5 \%$ ) akibat berkurangnya efek interferensi seiring bertambahnya angka Froude.

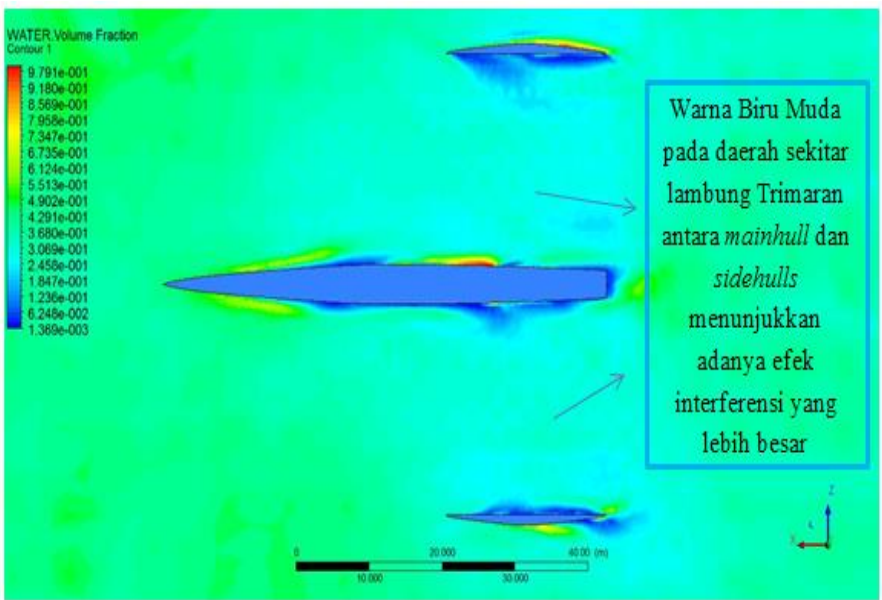


Gambar 14. Simulasi CFD Interferensi Gelombang pada ก. $\cap \cap c$

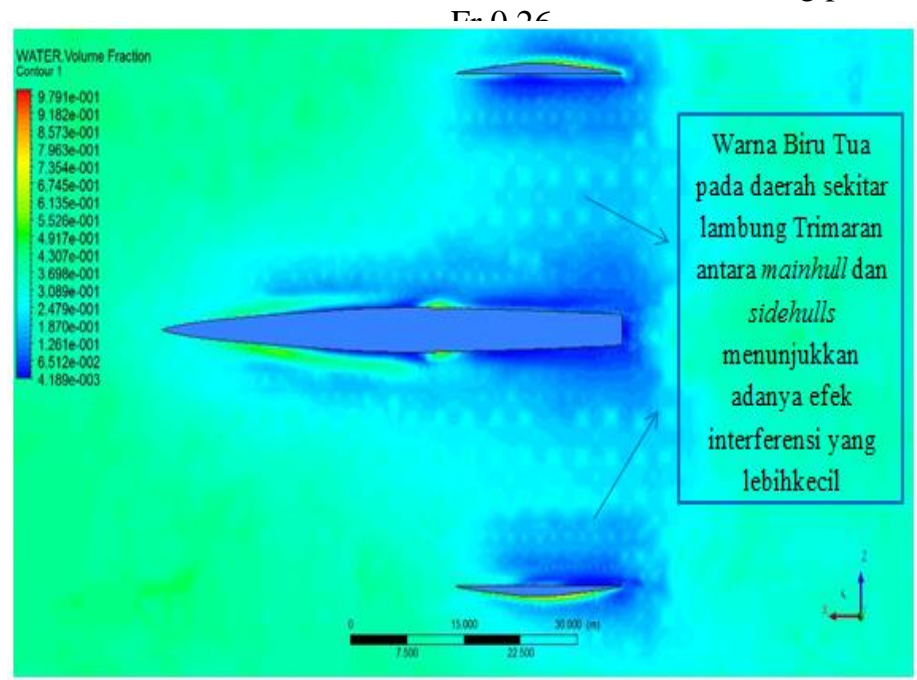

Gambar 15. Simulasi CFD Interferensi Gelombang pada Fr 0,48

Gambar 14 dan Gambar 15 merupakan hasil simulasi CFD untuk dua variasi kecepatan yaitu pada saat Fr 0,26 (efek interferensi yang lebih besar) dan Fr 0,48 (efek interferensi yang lebih kecil. Dapat dilihat bahwa, pada dua variasi kecepatan tersebut terdapat perbedaan kontur volume fraksi gelombang, dimana warna biru muda menunjukkan nilai gelombang yang lebih besar dibandingkan dengan warna biru tua.

\section{KESIMPULAN DAN SARAN}

\section{V.1 Kesimpulan}

Setelah didapatkan hasil penelitian dari CFD maka kesimpulannya sebagai berikut:

1. Semakin jauh letak jarak antar lambung secara membujur $\mathrm{R} / \mathrm{L}$, maka semakin berkurang hambatan total kapal yang terjadi.

2. Model $\mathrm{C}$ adalah model paling baik dalam penelitian ini karena menghasilkan hambatan kekentalan dan hambatan total terkecil dari semua variasi model.

3. Pada Fr 0,26 sampai 0,35 maka nilai hambatan total lebih dipengaruhi oleh hambatan gelombang, sedangkan pada angka Froude diatas 0,35 tepatnya 0,48 , nilai hambatan total lebih dipengaruhi oleh hambatan kekentalan.

4. $\mathrm{S} / \mathrm{L}=0,4$ pada kapal Trimaran flat side inside masih terdapat efek interferensi jadi hanya bertujuan untuk meminimalisir efek interferensi tersebut.

V.2 Saran

Adapun saran dalam penelitian ini adalah sebagai berikut:

1. Variasi kecepatan, variasi bentuk lambung kapal Trimaran dan variasi R/L yang bisa lebih diperbanyak untuk penelitian selanjutnya.

2. Penggunaan dynamic mesh dalam pemodelan menghasilkan pemodelan free surface yang lebih baik.

\section{UCAPAN TERIMA KASIH}

"Penulis A.G. mengucapkan terima kasih kepada Saudara Sutiyo yang telah memberikan saran dan ilmunya mengenai penggunaan CFD dalam penelitian ini"

\section{DAFTAR PUSTAKA}

[1] Insel, M. \& Molland, A.F. 1990. An Investigation into the Resistance Components of High-speed Displacement Catamarans. PhD thesis, University of Southampton.

[2] Javanmardi, M.R. 2008. Hydrodynamic Analysis of Trimaran Vessels. Polish Maritim Research 1(55) 2008 vol. 15 pp. 11-18.Data-data kapal, propulsi dan ESD oleh Pertamina (PERSERO) Shipping. Jakarta, Indonesia.

[3] Konstantin, I.M. \& Victor, A.D. 2006. Aerodynamic characteristics of a hybrid Trimaran model. ScienceDirect, Ocean Engineering 34 616-620.

[4] Dubrovsky, V. 2001. Multi Hull Ships. New York : Backtone Publishing Company.

[5] Ackers, B.B., Michael, T.J., Tredennick, O.W., Landen, H.C., Miller, I.E.R., Sodowsky, J.P., Hadler, J.B. 1997. An Investigation of the Resistance Characteristics of Powered Trimaran Side-hull Configurations, Trans. Of Society of Naval Architects and Marine Engineers, Vol. 105, pp 349-373.

[6] Bertram, V. 2002. Practical Ship Hydrodinamics, Butterworth Heineman, Oxford.

[7] Fathoni, M.A. 2012. Studi Eksperimental Tahanan dan Momen Melintang Kapal Trimaran Terhadap Variasi Posisi Dan Lebar Sidehull, Institut Teknologi Sepuluh Nopember, Fakultas Teknologi Kelautan, Jurusan Teknik Perkapalan, Surabaya.

[8] Purnamasari, R. 2012. Analisa Hambatan pada Kapal Trimaran Asimetrik dengan Konfigurasi jarak antar lambung secara membujur (R/L), Universitas Indonesia, Depok, Jakarta.

[9] Carr, B. \& Dvorak, R. 2007. Investigation of Trimaran Interference Effects, Glen Cove, New York.

[10] Bao-Ji, Z. 2008. The Optimalization Of The Hull Form with The Minimum Wave Making Resistance Based on Rankine Source Method, Journal of Hydrodynamics, pp.277-284. 